\title{
USE OF RIVER HABITAT SURVEY TO DETERMINE THE SPAWNING HABITAT CHARACTERISTICS OF TWAITE SHAD (ALOSA FALLAX FALLAX).
}

\author{
P.A. CASWELL, M.W. APRAHAMIAN \\ Environment Agency, North West Region, Richard Fairclough House, Knutsford Road, \\ WARRINGTON, WA4 1HG, UK.
}

Reçu le 30 septembre 2000

Accepté le 25 juin 2001

Received 30 September, 2000

Accepted 25 June, 2001

\begin{abstract}
The spawning habitat of twaite shad comprises a fast-flowing shallow area of unconsolidated gravel/pebble and/or cobble substrate. The River Habitat Survey flow types "smooth flow ", "rippled flow " and " unbroken standing waves " were significantly $(P<0.05)$ associated with the presence or absence of shad eggs. The presence of eggs was significantly associated with the higher energy flow types "rippled flow " and " unbroken standing waves ", and the absence of eggs was significantly associated with the lower energy flow type « smooth flow ».
\end{abstract}

Key-words : Alosa fallax fallax, spawning habitat, River Habitat Survey.

\section{UTILISATION DU « RIVER HABITAT SURVEY » AFIN DE DÉTERMINER LES CARACTÉRISTIQUES DE L'HABITAT DE PONTE DE L'ALOSE FEINTE (ALOSA FALLAX FALLAX).}

\section{RÉSUMÉ}

L'habitat de ponte de l'alose feinte est constitué d'une zone à flot rapide ayant un substrat non consolidé de graviers/cailloux et/ou de pierres/galets. Les types de flots « flot lisse ", " ondulations » et "vagues stationnaires sans écume » du "River Habitat Survey " étaient significativement $(P<0,05)$ associés avec la présence ou l'absence d'œufs d'alose. La présence d'œufs était significativement associée avec les types de flots à haute énergie "ondulations " et "vagues stationnaires sans écume ", et l'absence d'œufs était significativement associée avec le type de flot à faible énergie « flot lisse ».

Mots-clés : Alosa fallax fallax, habitat de ponte, « River Habitat Survey ».

\section{INTRODUCTION}

Twaite and Allis shad (Alosa fallax and Alosa alosa) are nationally rare species and protected by national and international legislation. Twaite shad are only known to spawn in four rivers in the UK : the Wye, Usk, Severn and Tywi ; and there are no known UK spawning populations of allis shad (APRAHAMIAN and APRAHAMIAN, 1990). Spawning has been reported in tidal fresh water (HASS, 1968 ; TAVERNY, 1991 ; THIEL et al., 1996), as well as in the non-tidal river (EHRENBAUM, 1894 ; MOHR, 1941 ; APRAHAMIAN, 1982) with fish migrating as far as $400 \mathrm{~km}$ from the sea (MANYUKAS, 1989). In the River Wye, A. fallax prefer to deposit their eggs over shallow gravel/pebble shoals (APRAHAMIAN, 1982), while in France, spawning substrate has ranged from mud 
to cobble (ANON, 1979 ; CASSOU-LEINS and CASSOU-LEINS, 1981 ; TAVERNY, 1991). In the River Elbe, $A$. fallax spawns in tidal fresh water where the eggs are maintained in the water column, by the current (HASS, 1968 ; THIEL et al., 1996).

The aim of this study was to characterise the spawning habitat of shad in Britain in terms of River Habitat Survey (RAVEN et al., 1997), as the first part of a larger programme of understanding the species' freshwater habitat requirements.

\section{MATERIAL AND METHODS}

Sampling was carried out in the summers of 1999 and 2000, at 19 sites on the River Wye, 8 sites on the River Usk, 4 sites on the River Tywi and 1 site on the River Teme, a tributary of the River Severn (Figure 1).

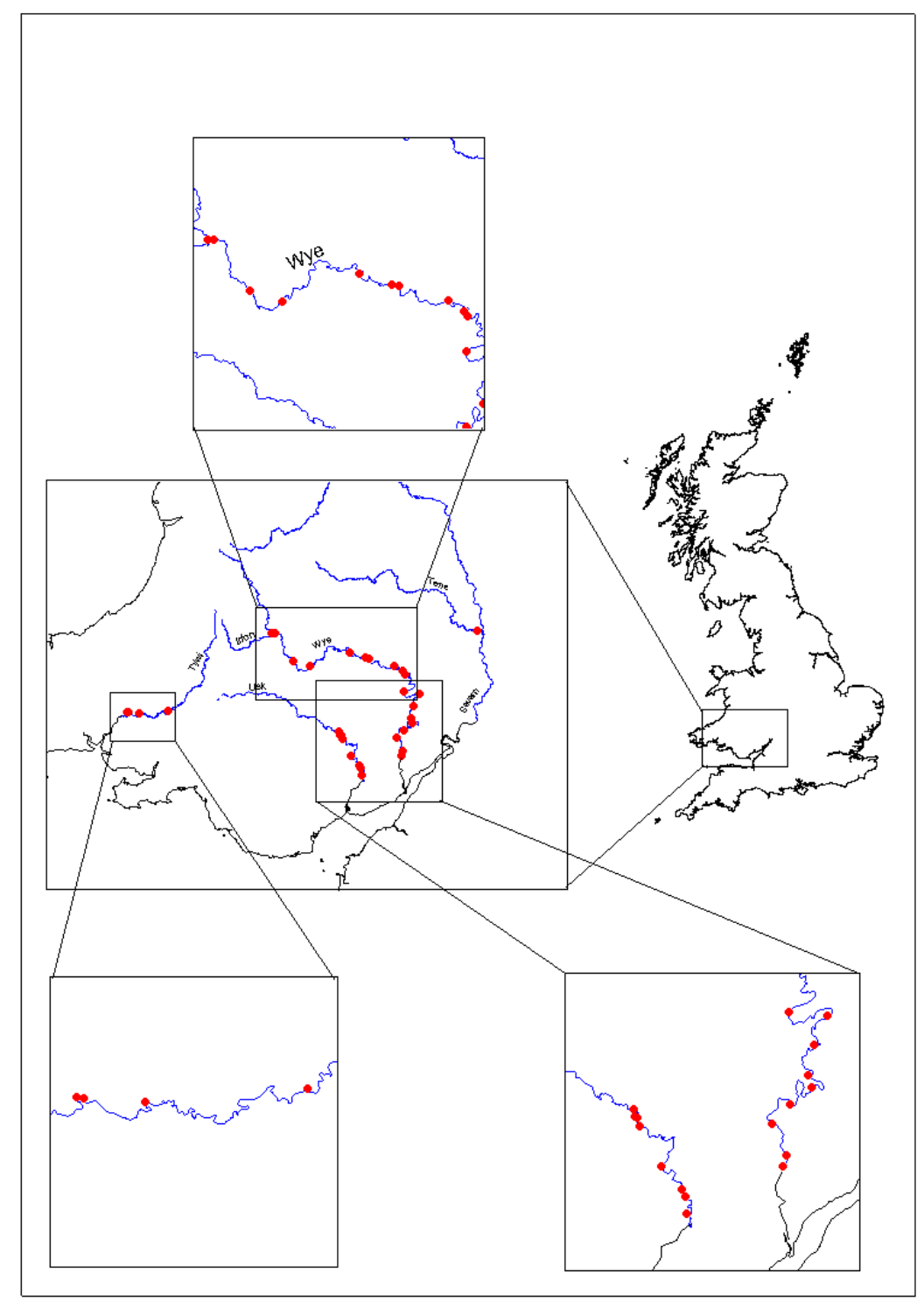

\section{Figure 1}

Study area showing the location of spawning sites $(\bullet)$.

\section{Figure 1}

Zone d'étude montrant la localisation des sites de pontes $\left({ }^{\bullet}\right)$. 
Sites where spawning activity had been reported were selected for the study. A preliminary survey, utilising the kick sampling method, was carried out at each site, to confirm the presence or absence of eggs. Kick sampling was used as the eggs are demersal and the results obtained are dependent on the amount of substrate dislodged as opposed to the amount of water filtered. Kick sampling was carried out using a standard macro invertebrate hand net (width $=200 \mathrm{~mm}$; height $=250 \mathrm{~mm}$; mesh $=250 \mu \mathrm{m}$ ). The net was held vertically and the substrate upstream of the net was dislodged by kicking to a depth of $100 \mathrm{~mm}$ for $15-30$ seconds. The net was held close enough to the area being disturbed so that the eggs flowed into the net with the current. The net was checked for eggs after each kicking interval and any detritus or channel substrate removed before kicking resumed. If no eggs were found, the survey was terminated (a comprehensive assessment was judged to comprise approximately 25 kicks, or 30-40 minutes). If eggs were present, the extent of the spawning area was determined by progressively kick sampling $($ c. $10 \mathrm{~m})$ upstream and downstream. To confirm the limit of a spawning area, sampling was continued for at least another interval after the last egg was recorded.

The River Habitat Survey (RHS) (RAVEN et al., 1997) was used to report on the physical structure of each site. Data collection was based on a $500 \mathrm{~m}$ length of river channel and comprised two sections : spot checks and sweep up. Ten spot checks were taken at equal distances $(50 \mathrm{~m})$ along the site, and recorded an assessment of flow types, physical features, bank top vegetation structure and land use, and channel vegetation types. Physical attributes were assessed over a $1 \mathrm{~m}$ wide transect across the channel, while vegetation structure, land use and channel vegetation were recorded within a $10 \mathrm{~m}$ wide transect across the river. The sweep up comprised an overall assessment of the site, recording its general nature and features not picked up by spot checks. For more details see RAVEN et al. (1998).

One RHS reach consisted of $500 \mathrm{~m}$, so in some cases more than one RHS was carried out along a spawning site in order to make sure its full length was covered. The survey generally included areas where no eggs had been found as well as the defined spawning site (e.g. a survey might start $200 \mathrm{~m}$ upstream of the spawning area and finish 150 m downstream).

\section{A) Sweep up data}

Elements such as land use and bank profile consisted of a variable for each bank. To produce a single variable for each element at each site, the information was amalgamated and converted into codes using the rules presented by NAURA and ROBINSON (1998). The extent of tree cover along each bank was recorded on a six-point scale from none to continuous. This information was translated to a numeric scale of $0-5$. Scores for each bank were then added to give an estimate of tree cover ranging from 0 (none on each bank) to 10 (continuous cover on each bank).

Other elements, such as features of flow, channel features and tree features, were assessed as being absent, present ( $>1 \%$ of the area) or extensive ( $\geq 33 \%$ of the area). This information was translated into a three-point scale from 0-2. Information from spotchecks was used to give a comparable view of channel substrate (sand $<2 \mathrm{~mm}$; gravel 2-16 $\mathrm{mm}$; pebble 16-64 $\mathrm{mm}$; cobble 64-256 $\mathrm{mm}$; boulder > $256 \mathrm{~mm}$ and bedrock), as this was not assessed in the sweep up in a similar manner to other elements. The substrate was classified as either consolidated, the bed «feeling " stable or with macrophyte growth on the gravel or unconsolidated where the substrate could be dislodged easily when kicked. 


\section{B) Spawning and non-spawning spot checks}

For some spawning sites, the area over which eggs were found (the distribution of spawning) within the reach was known. Spot checks where the category "non visible " had been recorded for substrate type were removed, as it implied that substrate could not be seen or accessed due to depth of channel, and hence the presence or absence of eggs could not be confirmed. Spot checks were split into two groups : "spawning » and «non spawning ", according to whether eggs had been found or not.

\section{Analysis}

River Habitat Survey variables from the RHS spot check and sweep up sections were used in the analysis.

Data from the whole of each spawning site were used to give a general picture of a spawning site. In addition, the spot checks were split up into "spawning " and "nonspawning " spot checks according to whether eggs had been found. Binary Logistic Regression and the Chi-squared test were employed to test for any association between the presence and absence of eggs and each flow type and substrate type. The level of significance was $5 \%$, the null hypothesis being that there was no significant association between these variables.

\section{RESULTS}

RHS were carried out at 32 spawning sites, giving a total of 40 reach surveys. The distribution of spawning was known at 21 sites (comprising 27 RHS reaches), where 269 spot checks were measured in all. Of these, eggs had been found at 157, 93 had been measured where no eggs had been found, and 19 were removed because of the category «non-visible».

\section{General features of a typical spawning site}

The main features of shad spawning sites are summarised in Figure 2. Predominant land uses were improved grasslands, broad-leafed/mixed woodland and suburban/urban land. Bank profiles were mixed, with steep banks $\left(>45^{\circ}\right)$, vertical undercut banks and gentle banks being common. Bank modification such as resectioning or reinforcement was present at half of the sites, though poaching was only found at $15 \%$ of sites. The majority of sites had good tree cover, and associated features such as shading of the channel, overhanging boughs and underwater tree roots were also present at most sites. Unvegetated side bars were found at $66 \%$ of sites.

Flow types typically found at a spawning site include glides and runs (present at all sites) and riffles (present at $97 \%$ of sites). Glides were extensive (occurring $\geq 33 \%$ of the site) at $66 \%$ of sites. Marginal deadwater was present at $91 \%$ of sites, and other flow features, occurring, included rapids, boils, pools and ponded reaches.

Pebble, gravel and cobble were the dominant channel substrates in the spawning sites surveyed. Pebble and gravel were present at $94 \%$ and $88 \%$ of sites respectively, and extensive at $44 \%$ and $54 \%$ of sites respectively. Cobble was present or extensive at $53 \%$ of sites. The category «non visible » was recorded at $56 \%$ of sites. At all sites at the point where channel dimensions were recorded, substrate was unconsolidated.

$97 \%$ of sites sampled had channel widths of between $20 \mathrm{~m}$ and $70 \mathrm{~m}$. All water depths sampled were $1.0 \mathrm{~m}$ or less, but $94 \%$ fell between $0.2 \mathrm{~m}$ and $0.7 \mathrm{~m}$ depth. 

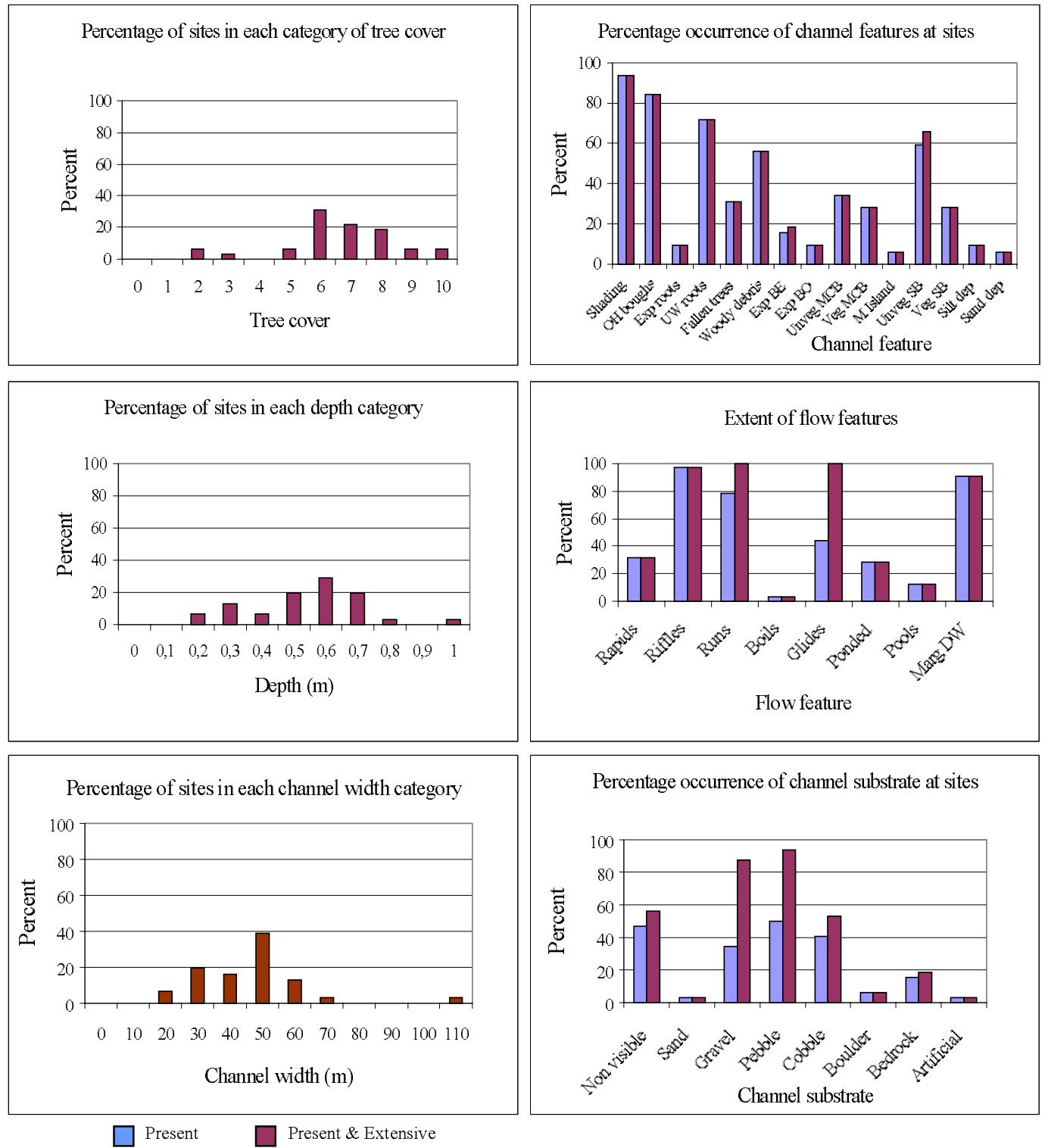

\section{Figure 2}

Features of shad spawning sites. $(\mathrm{OH}$ Boughs Overhanging boughs ; Exp roots Exposed roots ; UW roots Underwater tree roots ; Exp BE Exposed bedrock ; Exp BO Exposed boulder ; Unveg МСВ Unvegetated midchannel bar ; Veg МСВ Vegetated midchannel bar ; M Island Mature Island ; Unveg SB Unvegetated side bar ; Veg SB Vegetated side bar ; Silt dep Discrete silt deposit ; Sand dep Discrete sand deposit ; Marg DW Marginal Deadwater ; Ponded Ponded Reach).

Figure 2

Caractéristiques des sites de ponte de l'alose. (OH Boughs branchages suspendus ; Exp roots racinaire apparent ; UW roots racines filamenteuses submergées ; Exp BE lit rocheux apparent ; Exp BO blocs émergents ; Unveg MCB banc(s) médian(s) non végétalisé(s) ; Veg MCB banc(s) médian(s) végétalisé(s) ; M Island île(s) formée(s) ; Unveg SB banc(s) latéral(aux) non végétalisé(s); Veg SB banc(s) latéral(aux) végétalisé(s) ; Silt dep traces de dépôt vaseux ; Sand dep traces de dépôt sableux ; Marg DW eaux mortes (abris, reculée); Ponded retenue(s)). 


\section{Spot check composition of a typical spawning site}

Smooth flow (SM) was most common, occurring on average at 5 out of 10 spot checks (Figure 3a). Smooth flow is characteristic of glides. Rippled flow (RP) occurred on average at 3.5 out of 10 spot checks, and typifies a run. Unbroken standing waves (UW), indicative of riffles, were present at 1 spot check on average. This correlates with the sweep up data, which found glides and runs present at every site and riffles present at $97 \%$ of sites.

On average, gravel and pebble were each present at 3.7 spot checks (Figure 3b). Cobble featured at 1.2 spot checks, and the category « Non-visible » occurred at 0.9 spot checks on average. In decreasing order of occurrence after these substrates came bedrock, then boulder, sand and artificial substrate.

a) Flow type

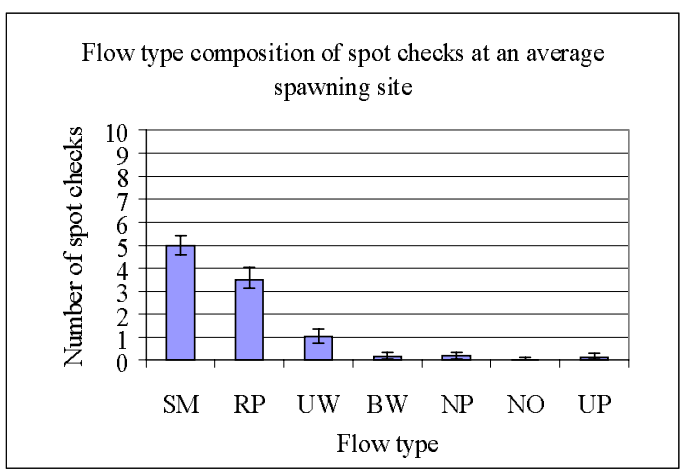

b) Substrate

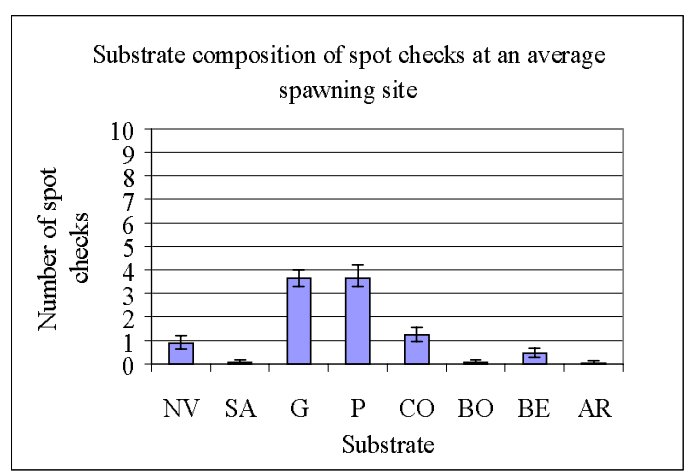

$I=$ Confidence Interval

Figure 3

Composition of spot checks at an average spawning site a) flow type b) substrate (SM smooth flow ; RP rippled flow ; UW unbroken standing waves ; BW broken standing waves ; NP no perceptible flow ; NO no flow ; UP upwelling ; NV non visible ; SA sand ; G gravel ; P pebble ; CO cobble ; BO boulder ; BE bedrock ; AR artificial).

Figure 3

Composition des "spot checks "à un site de ponte moyen a) type d'écoulement b) fond du lit (SM lisse ; RP ondulations ; UW vagues stationnaires sans écume ; BW vagues stationnaires cassées (écume) ; NP écoulement non perceptible ; NO pas d'écoulement (assec) ; UP Upwelling ; NV non visible ; SA sable ; G graviers ; P cailloux ; CO pierres, galets ; BO blocs ; BE fond rocheux ; AR artificiel).

\section{Spawning and non-spawning spot checks}

Factors shown to be significantly associated with the presence and absence of eggs by both tests $(P<0.05)$ were smooth flow, rippled flow, and unbroken standing waves. Substrate was not significantly associated with eggs.

Rippled flow, representative of runs, was significantly associated with the presence of eggs and was the dominant flow type at $52.4 \%$ of "spawning " spot checks at an average site (Figure 4a). In contrast, rippled flow was present at only $17.2 \%$ of nonspawning site spot checks at an average site (Figure 4b). Smooth flow, representing 
glides, was significantly associated with the absence of eggs, and was present at $31.5 \%$ and $69.0 \%$ of spawning and non-spawning spot checks, respectively, at an average site. Unbroken standing waves (found in riffles) were significantly associated with the presence of eggs, and were present at $14.0 \%$ and $5.3 \%$ of spawning and non-spawning spot checks, respectively, at an average site.

a) spawning

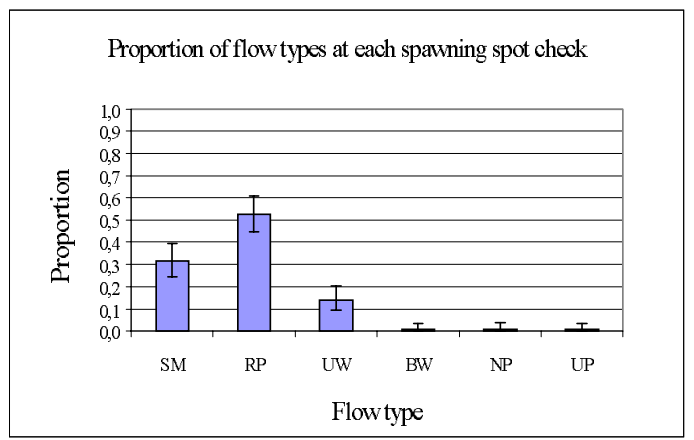

b) non-spawning

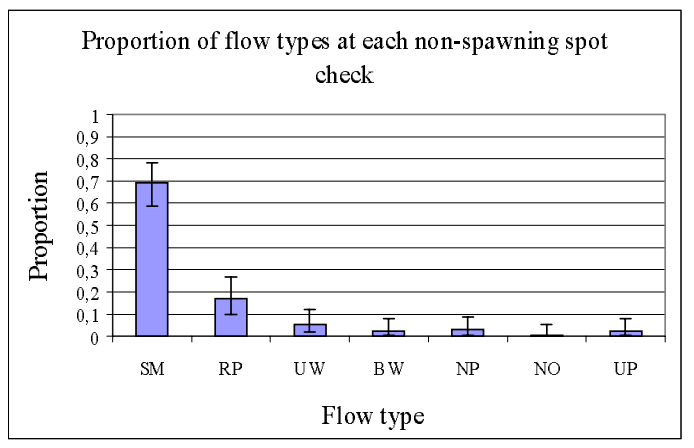

Figure 4

Proportion of flow types at spot checks at an average site ( $I=95 \%$ confidence interval) (SM smooth flow ; RP rippled flow ; UW unbroken standing waves ; BW broken standing waves ; NP no perceptible flow ; NO no flow ; UP upwelling).

\section{Figure 4}

Proportion des types de flots au "spot checks" à un site moyen (I = $95 \%$ intervalle de confiance) (SM lisse ; RP ondulations ; UW vagues stationnaires sans écume ; BW vagues stationnaires cassées (écume) ; NP écoulement non perceptible ; NO pas d'écoulement (assec) ; UP Upwelling). (Figure 5).

Substrate was not significantly associated with the presence or absence of eggs

a) spawning

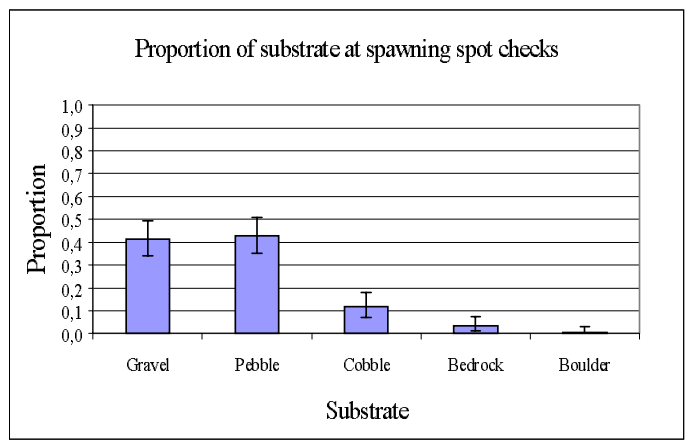

b) non-spawning

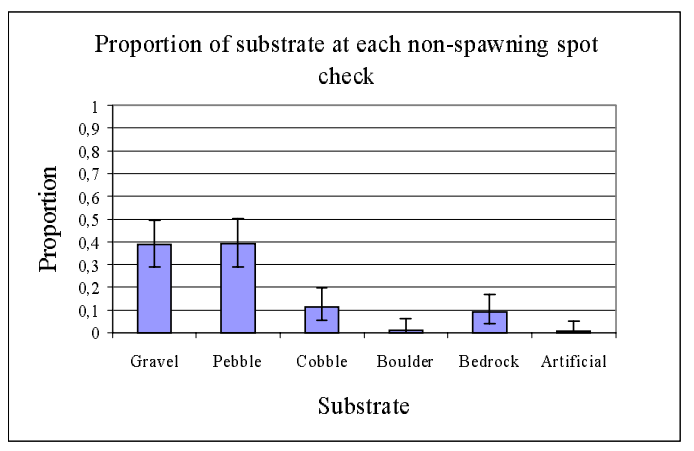

Figure 5

Proportion of substrates at spot checks at an average site $(I=$ confidence interval), a) spawning and b) non-spawning.

\section{Figure 5}

Proportion des substrats au "spot checks " à un site moyen (I= intervalle de confiance), a) ponte et b) pas de ponte. 


\section{DISCUSSION}

\section{General characteristics of a spawning site}

Improved/semi-improved grass was the most common land use at the spawning sites, together with Broad-leafed woodland reflecting the largely rural nature of the catchments. Cattle were the predominant grazers. Although urban development occurred sporadically along each river, it did not seem to adversely affect the location of spawning sites.

Flow over a spawning site was composed of glides, runs and riffles. Glides are characterised by smooth flow, runs by rippled flow and riffles by the presence of unbroken standing waves. The sweep up and spot check data corroborate each other (see results). Glides covered most of a spawning site, with the rest of the flow being made up of runs, and a small proportion of riffles. This shows the make up of a riffle/pool sequence*; riffles were generally smaller, more discrete features than the runs or glides observed, so the characteristic unbroken standing waves did not appear so frequently at spot checks. Runs are often associated with riffles just upstream (ENVIRONMENT AGENCY, 1997). The difference between glides and runs, apart from their characteristic flow types, is that runs are a higher energy feature. A typical spawning site may therefore comprise predominantly slower flow with smaller areas of higher energy flow.

Marginal deadwater was present at $91 \%$ of sites. This may be a coincidental feature or may be an important habitat feature with $A$. fallax having similar requirements to Alosa alosa larvae, which on hatching migrate, into the channel margins (CASSOU-LEINS et al., 1988). WHEELER (1978) states that, on hatching, larvae lie immobile in the gravel for a few days before being swept into « quieter » waters, and APRAHAMIAN (1982) found juveniles in deep pools with slow currents. Such habitats may be classified as marginal deadwaters during a River Habitat Survey : "marginal areas with no perceptible flow ». This is similar to the findings of GERKENS and THIEL (2001) in the Elbe estuary where larval $A$. fallax were found to be more abundant in the side-channels, which because of their slower currents, were considered to provide better nursery and feeding areas than the main channel.

Pebble and gravel were the dominant substrates at spawning sites, a result similar to those reported by BRACKEN and KENNEDY (1967), RAMEYE et al. (1976), WHEELER (1978) and APRAHAMIAN (1982). Eggs were always found in gravel/pebble substrate ; even at sites where the dominant substrate was recorded as something other than pebble or gravel (for example, bedrock), eggs were found in gravel/pebble pockets.

"Non-visible» substrate was recorded at half of the sites surveyed, and was present at 0.9 spot checks at an average site. In such instances, the substrate could not be seen or accessed due to the depth of the channel ( $>1 \mathrm{~m}$ deep, generally), therefore the result "non-visible " was taken to be indicative of deeper water. These areas may represent the holding pools used by adult shad to rest in prior to spawning.

Bank profiles varied, with gently sloped banks and vertical or steep banks present at many sites. Poaching of the banks occurred at only $15 \%$ of sites, indicating that livestock access to the channel was limited, which would mean reduced bank erosion and siltation. Clean gravels are important in allowing successful incubation of eggs (RAMEYE et al., 1976).

* N.B. A riffle/pool sequence in the general sense is a sequence of alternating shallow, fast flow, coarse substrate areas, and deeper, slower flow, finer substrate areas. In RHS terms, a pool is a natural feature of deeper water, with no perceptible flow in dry weather conditions, which occupies most of the wetted channel width. 
Most sites had good tree cover along both banks, and therefore had some degree of shading. It is not known whether shading is an important habitat feature for spawning shad, however, trees lining the bank are an important general habitat feature, as bank side vegetation cover reduces bank erosion and the leaching of nutrients into the channel (PIERCE et al., 1970).

The presence of unvegetated channel bars indicates regular sediment transport events. The presence of unconsolidated substrate indicates the regular turnover of substrate. Together, these factors indicate an active river system. Substrate is likely to be frequently moved by flow, ensuring the removal of accumulated fines and therefore probably contributing to the survival of eggs.

Water depth and width were taken from one point on the $500 \mathrm{~m}$ RHS stretch (ENVIRONMENT AGENCY, 1997), and therefore were not necessarily representative of the depth and width of a spawning site. Although not quantified in this study, depth at which eggs were found was almost always less than $1.0 \mathrm{~m}$. The majority of eggs were found at depths of between $0.2 \mathrm{~m}$ and $0.7 \mathrm{~m}$, with the most common depth class being $0.2 \mathrm{~m}-0.3 \mathrm{~m}$. A study by APRAHAMIAN (1982) showed that the optimum egg density occurred at depth $0.3 \mathrm{~m}$. These conditions contrast with those of the Elbe estuary where the fish spawn in tidal fresh water in depths of up to 8.0 to $9.5 \mathrm{~m}$ with peak egg densities occurring at depths more than $4 \mathrm{~m}$ from the surface (HASS, 1968 ; THIEL et al., 1996).

\section{Spawning and non-spawning spot checks}

Flow type, but not substrate type, was significantly associated with the presence or absence of eggs.

The general flow pattern of a spawning site comprised large areas of glides, with some runs and a smaller area of riffles, similar to the flow patterns reported by BRACKEN and KENNEDY (1967), WHEELER (1978) and APRAHAMIAN (1982). Analysis of spot check data revealed that smooth flow (glides) was significantly associated with the absence of eggs, whereas rippled flow (runs) and unbroken standing waves (riffles) were significantly associated with the presence of eggs. Riffles are shallow, high-energy features and runs have relatively high-energy flows compared to glides. Eggs may be preferentially released in the proximity of higher energy flows to ensure high oxygen levels in the incubating environment

Substrate type was not significantly associated with the presence or absence of eggs. Substrate composition was similar (gravel/pebble) at both spawning and nonspawning spot checks. This result was due to the nature of the rivers investigated; that is, extensive gravel/pebble substrate in the areas surveyed. Depth surveyed was limited due to access problems ; substrate type could not be ascertained in stretches of channel that were un-wadeable, and in such situations it was recorded as «non-visible ». Changes in substrate, such as increased silt, would therefore have gone unrecorded in these areas. Spot checks that recorded «non-visible » substrate were removed from the analysis, as the absence of eggs could not be confirmed.

\section{CONCLUSION}

A typical $500 \mathrm{~m}(\mathrm{RHS})$ stretch of river that contained spawning ground of the twaite shad was dominated by gravel/pebble substrate $(2-64 \mathrm{~mm})$, and included some cobbles. The dominant flow type was smooth flow, with some rippled flow and a small amount of unbroken standing waves (spot checks), and glides, runs and riffles were present (sweep up). Shallow areas occurred (water $<1.0 \mathrm{~m}$ depth), but deeper areas were also likely (indicated by substrate being recorded as «non-visible» at a spot check). Marginal 
deadwater and channel bars (side-, point-, or mid-channel bars) were likely to be present. Eggs were more likely to be found at spot checks with rippled flow or unbroken standing waves than smooth flow. Also, eggs were likely to be found in water of depths less than $0.8 \mathrm{~m}$.

The survey method (wading) was limiting in that deep, un-wadeable areas of the channel could not be investigated. Depths up to 1.2 or $1.3 \mathrm{~m}$ were sampled for eggs, which was often enough to ascertain the limits of a spawning area. However, in deeper sections, the absence of eggs could not be confirmed. The River Habitat Survey gives a general physical description of river habitat. More detailed descriptions may be needed to give a complete picture of the spawning habitat of twaite shad.

\section{ACKNOWLEDGEMENTS}

We also thank J. HILLARY, J. HATELEY and K. NASSAR for their very valuable assistance. The project was funded by the Environment Agency (R\&D Project W1-014). The views expressed in this paper are those of the authors and not necessarily those of the Environment Agency.

\section{BIBLIOGRAPHY}

ANON, 1979. Etude halieutique de l'estuaire de la Gironde. Rapport CTGREF div. ALA Bordeaux, $189 \mathrm{p}$.

APRAHAMIAN M.W., 1982. Aspects of the biology of the twaite shad, Alosa fallax fallax (Lacépède), in the Rivers Severn and Wye. Ph.D. Thesis, Liverpool University.

APRAHAMIAN M.W., APRAHAMIAN C.D., 1990. Status of the genus Alosa in the British Isles ; past and present. Journal Fish Biology, 37 (Suppl. A), 257-258.

BRACKEN J., KENNEDY M., 1967. Notes on some Irish estuarine and inshore fishes. Irish Fisheries Investigations, Series B (Marine) 3, 1-28.

CASSOU-LEINS F., CASSOU-LEINS J.J., 1981. Recherches sur la biologie et l'halieutique des migrateurs de la Garonne et principalement de l'alose, Alosa alosa L. Doctorate $3^{e}$ Series thesis. Institute National Polytechnique de Toulouse, Toulouse, France.

CASSOU-LEINS F., CASSOU-LEINS J.J., DAUBA F., LEJOLIVET C., 1988. Réserve naturelle de la frayère d'alose d'Agen, campagne 1988 étude de l'alevin d'alose Alosa alosa L, répartition, croissance, régime alimentaire, RAP. Lycée Agricole de Montaubon/ ENSAT, $24 \mathrm{p}$.

EHRENBAUM E., 1894. Beiträge zur Naturgeschichte einiger Elbfische (Osmerus eperlanus L., Clupea finta Cuv., Acerina cernua L., Acipensar sturio L.). Wissenschaftliche Meersunterchungen Helogoland, 1, 54-63.

ENVIRONMENT AGENCY, 1997. River habitat survey. Field survey guidance manual incorporating SERCON. Environment Agency, Bristol, UK 124 p.

GERKENS M., THIEL R., 2001. Habitat use of age-0 twaite shad (Alosa fallax Lacépède, 1803 ) in the tidal freshwater region of the Elbe River, Germany. Bull. Fr. Pêche Piscic, 362/363, 773-784.

HASS H., 1968. Untersuchungen über die vertikale und horizontale Verteilung der Eier der Finte. Alosa fallax (Lacépède, 1803) in der Elbe. Archiv für Fischereiwissenschaft, 19, 46-55.

MANYUKAS Y.L., 1989. Biology of the Atlantic shad, Alosa fallax fallax, in Kurshskiy Bay. Journal of Ichthyology, 29, 125-128.

MOHR E., 1941. Maifische (Clupeiden). In DEMOLL R., MAIR H. N. (Eds.), Handbuch der Binnenfischerei Mitteleuropas, 527-551, Schweizerbart'sche Verlagsbuchhandlung, Stuttgart. 
NAURA M., ROBINSON M., 1998. Principles of using River habitat survey to predict the distribution of aquatic species : an example applied to the native white-clawed crayfish Austropotamobius pallipes. Aquatic Conservation : Marine and Freshwater Ecosystems, 8, 515-527.

PIERCE R.S., HORNBECK, J.W., LIKENS, G.E., BORNMANN, F.H., 1970. Effect of elimination of vegetation on stream water quality and quantity. International Association of Hydrological Scientists, 96, 311-328.

RAMEYE L., KEINER A., SPILLMANN C.P., BIOUSSE J., 1976. Aspect de la biologie de l'alose du Rhône - Pêches et difficultés croissantes de ses migrations. Bull. Fr. Pêche Piscic., 263, 50-76.

RAVEN P.J., FOX P., EVERARD M., HOLMES N.T.H., DAWSON F.H., 1997. River habitat survey : A new system for classifying rivers according to their habitat quality. In BOON PJ., HOWELL D.L. (Eds.), Freshwater quality : Defining the indefinable? The Stationery Office, Edinburgh. p. 215 - 234.

RAVEN P.J., HOLMES N.T.H., DAWSON F.H., FOX P., EVERARD M., FOZZARD I. R., ROUEN J., 1998. River habitat quality : the physical character of rivers and streams in the UK and Isle of Man. River habitat survey report $\mathrm{N}^{\circ} 2$, Environment Agency, Bristol.

TAVERNY C., 1991. Pêche, biologie, écologie des aloses dans le système GirondeGaronne-Dordogne contribution à la connaissance de la dynamique des populations d'aloses (Alosa alosa et Alosa fallax) dans le système fluvio-estuarien de la Gironde. Etudes CEMAGREF, Séries Ressources en eau, 4. 375 p.

THIEL R., SEPULVEDA A., OESMANN S., 1996. Occurence and distribution of twaite shad (Alosa fallax Lacépède) in the lower Elbe river, Germany. In KIRCHHOFER A., HEFTI D., (Eds.). Conservation of Endangered Freshwater Fish in Europe. 157170. Birkhäuser Verlag, Basel.

WHEELER A., 1978. Twaite and Allis shad. The Marshall Cavendish Fishermans's Handbook, 51, 1414-1421. 
